\title{
Rethinking Ecological Subalterns in Tanure Ojaide's The Activist
}

\author{
Innocent Chimezie Chukwulobe*, Zainor Izat Zainal, Hardev Kaur Jujar Singh \\ and Mohammad Ewan Awang
}

Department of English, Faculty of Modern Languages and Communication, Universiti Putra Malaysia, 43400 Serdang, Selangor, Malaysia

\begin{abstract}
This study explores the concept of subaltern and how its meaning has evolved over the years within the broader scope of postcolonial theory. The study shall trace the concept of subaltern from its anthropocentric meaning in Antonio Gramsci's writings to Ranajit Guha and Gayatri Spivak's ideological perspectives. We shall also trace its inroad into the ecocritical study in the works of Michael Egan and Sergio Ruiz Cayuela while maintaining its anthropocentric leaning. The study shall further attempt a redefinition of the subaltern concept to accommodate non-humans in the class of the subordinated social group. Bearing in mind the anthropocentric leaning of the concept of the subaltern, which excludes non-human members of the ecology, we shall redefine the term from its previous usage in environmental literary studies and expand it to include non-humans as a subordinated group. The study shall analyse the relationship between humans and nonhumans to determine if non-humans are treated as subordinates or worse than subordinated humans. The study shall draw instances from Tanure Ojaide's The Activist (2006) to justify the classification of non-humans as the ultimate ecological subalterns of the Niger Delta Environment. We shall consider human relationships with non-humans (land, air, water, animals, vegetation, sea lives) to determine their status as subalterns. The crux of the study is basically to expand the scope

ARTICLE INFO

Article history:

Received: 06 July 2021

Accepted: 04 October 2021

Published: 14 December 2021 of the subaltern theory by analysing the environmental despoliation prevalent in the oil-rich Niger Delta environments of Nigeria.
\end{abstract}

DOI: https://doi.org/10.47836/pjssh.29.4.38

E-mail addresses:

chimezieinnocent3@gmail.com (Innocent Chimezie Chukwulobe)

zainor@upm.edu.my (Zainor Izat Zainal)

hardevkaur@upm.edu.my (Hardev Kaur Jujar Singh)

ewan@upm.edu.my (Muhammad Ewan Awang)

* Corresponding author
Keywords: Environment, environmental subaltern, Niger Delta, postcolonial ecocriticism, subaltern 


\section{INTRODUCTION}

Like every other postcolonial country of the world, Nigeria is besieged with environmental challenges of various degrees and magnitude. The exploitation of oil in the Niger Delta area of Nigeria comes with environmental challenges that devastate the entire region, especially the non-human members. Why are the nonhuman members of the region most affected by the activities of humans in the region? Is it because they are of no worth or value? Or is it because they are considered objects to be exploited for human gains like every other subordinated group? Arguably, the exploitation of non-humans has its roots in colonialism, as envisaged by many literary scholars. DeLoughrey and Handley (2011) note that before colonialism in Nigeria, environmental devastation was almost nonexistent because industrial activities and mineral exploration and exploitation were minimal. Walter Rodney reiterates that "the institutionalisation of colonialism in Africa brought about capitalism" (1972, p. 107). Lock affirms that "it was during colonisation in Africa that exploration and exploitation of environment (human and non-human) began for commercial and economic purposes" (2000, p. 5). Literary writers and critics have been very vocal in expressing their concerns over the environmental devastation of the Niger Delta region due to unregulated oil exploitation by multinational oil companies, which have turned the region into a wasteland. Some of their concerns and advocacy for environmental justice are reflected in literary productions like
Kaine Agary's Yellow Yellow (2006), Helon Habila's Oil on Water (2012), Lawrence Amaeshi's Sweet Crude Odyssey (2017), and Tanure Ojaide's The Activist (2006). This study shall adopt Tanure Ojaide's The Activist (2006) as a primary text and draw instances to justify the exploitation of nonhuman members of the Niger Delta based on their subaltern status as captured in the novel.

\section{MATERIALS AND METHODS}

\section{Critical Framework}

Postcolonial ecocriticism is a literary theory that concerns itself with humans and their relationships with the environment. Literature no doubt reflects society; therefore, it represents societies along with their environmental situations and attributes. Huggan and Tiffin (2009) set the foundation for postcolonial ecocriticism in their text Postcolonial Ecocriticism: Literature, Animal, Environment. In the introductory note, they point out that the bourgeoning alliance between the two fields is difficult to read because of their contradictory and conflicting contexts and the insurmountable problems that bedevil the fields in terms of the difficulty in defining them even by their practitioners. They, however, suggest that a way out of it is that the subject of postcolonialism must be colonialism, as well as to look out for "colonial underpinning in environmental practices of colonising and colonised societies" (p. 3). Here they emphasise the importance of dismantling the "species boundary” (p. 6) between humans and non- 
humans. They relate environmental issues to racism and imperialism, where the perceived inferior races must be exploited just like nature. They opine that environmental issues are inherent in the ideas of imperialism and racism, and the Eurocentric perception of these ideas are used as a justification to continue exploiting different races just like nature. They also identify some major tasks of postcolonial ecocriticism to include aesthetics and its advocacy role and activism, which aims at providing alternatives to the Western concepts of development, as well as serving as an ecological lens to earlier postcolonial discourses in social, cultural, and political components that are related to the environmental crisis. They lay bare some of the conflicts that exist between human and non-human species. They insist that there are struggles for dominance between humans and non-human habitats of the universe. Most of these conflicts came about due to capitalists' ideals that emanated from colonial experiences. They also raised questions of rights and wrongs in the past and presented them through the focal point of representation. They question the very essence of granting rights as purely anthropocentric.

In the introductory part of Postcolonial Ecologies: Literatures of the Environment, DeLoughrey and Handley (2011) highlight and foregrounds postcolonial ecological concerns that reaffirm humans as part of nature. They traced the relationship before colonialism between humans and nonhumans in different societies in Africa, the Caribbean, and Asia. They drew instances from writers of these regions to validate their claims. They contend that it was "colonialism that altered the relationship which existed between human and land from "earth" and "landscape" to "property", and also "commercialized nature at large" (p. 5). In order to recover the relationship with nature that existed before colonialism, there is a need to establish another relationship of alterity that will upturn the present one. According to Haraway, as quoted in DeLoughrey and Handley, we must find "another relationship to nature beside reification and possession" (2011, p. 8) through imagination, which marks the central common ground between ecocritical and postcolonial criticism. In Postcolonial Ecologies: Literatures of the Environment, DeLoughrey and Handley (2011) aims at outlining a broader, more complex genealogy for thinking through ecocritical and postcolonial discourses as relating to the representations of alterity, human, and nature. At this point, it becomes obvious that the proposed genealogy will be a complete deviation from (Green Imperialism) the popular one that projects North American and Europe at the centre of ecological concerns, thereby bringing colonised societies from the margins to the centre. Having drawn attention to the poem of Martin Carter "Listening to the Land" (1951) and Chinua Achebe's Things Fall Apart (1958), which raised ecological concerns of colonised peoples long before the advent of North America and British experiments in the field, DeLoughrey and Handley (2011) propose to represent what 
colonised societies was before colonialism as well as show how these societies were altered by colonialism and imperialism, and this can be achieved by engaging a global perspective of the environment as against the national perspective of Anglo-American critics. DeLoughrey and Handley, therefore, agree that postcolonial environments are "internally complex" and "demand a necessary flexible approach;" they are motivated by different concerns from the mainstream American environmentalism, postcolonial ecologies emphasise issues related to "access to arable land and potable water, public health, threats of militarism and national debt, and reflect social planning for cultural, economic and national sovereignty" (2011, p. 16). Postcolonial and decolonising nations have debated these issues for decades in a way that firmly placed humans as part of nature, which distinguishes it from Anglo-American environmentalism.

Cajetan N. Iheka (2018), in Naturalizing Africa: Ecological Violence, Agency, and Postcolonial Resistance in African Literature lay more emphasis on African environmentalism. Drawing from a large body of literary works in the African continent, he draws attention to the devastating environmental challenges that bedevil various parts of the African continent. Using the concept of agency, Iheka draws attention to people's environmental attitudes all over the world. He contrasts the Shell BP oil spill of 2010 in the Gulf of Mexico, United States of America, the rapid responses it got from the Barrack
Obama administration and the then CEO of Shell BP in solving the problem to those of similar and worst scenarios in the NigerDelta of Nigerian and how it has been left unattended to since 1958. The contrast between handling similar situations in the United States of America and Nigeria is worrisome and a thing of concern to literary and environmental advocates in Nigeria. Hence, Iheka calls on all environmental writers to increase their efforts in terms of awareness as well as to pay equal attention to how environmental crises affect nonhumans and the symbiotic relations between humans and non-humans. He avers that placing a premium on human lives to the detriment of non-humans will only amount to the reifying of anthropocentrism that led to environmental crises in the first place.

He, however, shifts his focus from the effects of these crises on human species to non-human species. He moves away from the prevalent anthropocentric view to a more biotic view. Drawing attention to non-human species, he also states that he does not intend to favour nonhumans over humans but rather draw attention to the interdependence of both or what he terms as "Proximity." Finally, he argues that the relationship between humans and other life forms in African literature has a significant implication for rethinking the question of agency and resistance in postcolonial literature. This study shall therefore concentrate on non-humans as the major subaltern members of the Niger Delta Environment. 


\section{Non-Human Subaltern}

To elaborate on the history and concept of Gramscian concept of the subaltern, Buttigieg (2013) traces it to Gramsci's prison notes. The term 'subaltern' or 'subalternity' was used by Gramsci in his pre-prison and prison writings, sometimes in a conventional way and sometimes figuratively. His use of the term in Prison Notebooks marks the beginning of distinguishing the dominant class and the subordinated social or economic groups in a political and civil society. Gramsci consolidated on the histories and characteristics of the subaltern social groups in his Notebook 25 during his incarceration. The use of the term by Gramsci is quite eclectic and, therefore, difficult to pin down a definition attributive to Gramsci. It is because he does not regard them as a single, much less homogenous entity. Therefore, he refers to the subaltern groups in the plural term. For Gramsci, the subaltern social groups or classes comprise the working class or the proletariats and other component groups. Gramsci identified fragmentation as a distinguishing characteristic of the subaltern groups. He identifies that multiple subaltern groups are disconnected and quite different from one another, and there are also marginal and subaltern groups within the group (Buttigieg, 2013). The core interest of Antonio Gramsci in all his writing is "how to bring an end to subalternity, that is, to the subordination of the majority by the minority" (Buttigieg, 2013, p. 37). Therefore, the subaltern is a term used to refer to an officer in a subordinate position or 'of inferior rank'. Antonio Gramsci used the term to refer to the working masses that needed to be organised by left-wing intellectuals into a self-conscious political force (Habib, 2005). The term was used by Gramsci to refer to all the groups in a society that are subject to the hegemonic ruling classes. The subaltern classes may include workers, peasants, and other subordinated groups denied access to the 'hegemonic' power.

Bill Ashcroft, Gareth Griffiths, and Helen Tiffin (2007) in Post-Colonial Studies: The Key Concepts note that Gramsci was interested in the historiography of the subaltern classes since the prevailing and existing history were those of the ruling classes and an extension of that of the state. For Gramsci, the history of the subaltern social groups is always episodic and fragmented because they are always subjected to the activities of the ruling groups and because they lack access to cultural and social institutions. Therefore, he concludes that only a revolutionary class adjustment can break that pattern of subordination (Ashcroft et al., 2007). The term 'subaltern' was adopted into postcolonial studies from the works of the Subaltern Studies group of historians, whose aim was to promote a systemic discussion of subaltern themes in South Asian Studies. The group was formed by Ranajit Guha and initially included Shahid Amin, David Arnold, Partha Chatterjee, David Hardiman, Gyan Pandey.

Spivak (1994) in "Can the Subaltern Speak?" takes the idea of the subaltern further by identifying the exclusion of 
women, especially poor, black/colour, uneducated, rural women from colonised societies, as the most subjugated, most oppressed and the most subordinated group in a capitalist society. For her, these women, just like the peasants and other subordinated groups, cannot represent themselves; they must be represented. Moreover, their representatives often appear as their master, authority over them, and unrestricted government power to protect them from other classes. She maintains that "there is no unrepresentable subaltern subject that can know and speak itself; the intellectual's solution is not to abstain from representation" (p. 80). Spivak (1994) makes it clear here that though as subaltern, the female suffers more because she endures subjugation from the elite or capitalist or oppressor and from a subaltern male to whom she must also submit. Furthermore, as a result of this double submission, the subaltern woman is further relegated and more oppressed.

The term has also found its way into environmental studies. Michael Egan (2002) used the term to refer to the "victims of environmental injustice" (p. 22). For Egan, these are social and environmental victims, mostly poor and minority groups who suffer environmental hazards and unequal distribution of ecological resources. From Egan's description, non-humans can also fall into these categories of victims of environmental hazards. However, he seems to neglect them as well, as though they are inconsequential. Sergio Ruiz Cayuela (2018) used the term to designate marginalised communities who suffer environmental discrimination by the political and economic elites. It is also sometimes referred to as environmentalism from below. It is overwhelming that all the available references to the environmentalism of the subaltern, Subaltern Environmentalism, or what Nixon calls "Environmentalism of the Poor" are all anthropocentric in their theories. They all refer to humans: either men or women, marginalised or oppressed. In this study, we shall take a biocentric posture to capture the real subaltern, the ultimate victims of environmental pollution perpetrated by humans. We shall refer to them as "ecological subalterns". Environmental subalterns, for us, are the non-human members of nature that are mostly affected by human activities that cause environmental pollution. The subaltern here includes the land, air, water, trees, animals on land and in the sea, and the entire non-human members of the biosphere that is in one way or the other affected negatively by human environmental activities.

\section{RESULTS AND DISCUSSIONS}

\section{The Ecological Subalterns in Tanure Ojaide's The Activist}

The Niger Delta area and people of Nigeria are mostly referred to as "minorities" (Darah, 2011, p. 4), that is, subaltern groups in Nigerian. Worst still is the non-human species of the area. It will be insensitive to say that humans have suffered as much as non-humans in the Niger Delta society. Each has been affected in a different proportion. 
However, non-human appears to be the most affected because they are oppressed and exploited by human exploiters and the exploited among humans. Thus, they suffer doubly from humans' exploitative activities. In this regard, we consider nonhumans of the Niger Delta as subalterns and will further justify this claim by citing instances from Ojaide's (2006) The Activist to substantiate the claim. As a protest novel against the despoliation of the Niger Delta by oil exploration multinational companies; The Activist mirrors the state of the environment as occasioned by oil prospecting and exploitation activities of the companies. The oil companies, especially Bell Oil, are most culpable for destroying the environment with chemical wastes, leakages from worn-out pipes, and unconventional oil prospecting and exploitation procedures. The military government of Nigeria is a worthy accomplice in this crime against the non-human subaltern and the environment in general.

The narrator in The Activist reveals that Bell Oil Company has seriously damaged the Niger Delta. Succinctly put, the Niger Delta "had been seriously scarred by Bell Oil Company whose emblem of a redrimmed shell of yellow flames was seen all over the area" (Ojaide, 2006, p. 53). For the locals of the Niger Delta, the emblem of bell oil Company is symbolic of its destructive tendencies. It is unrelated to the oil “company's inordinate hunger for more barrels of oil to ship out to increase yearly record profits" (p. 53); consequently, they turned the area into a wasteland.
The once lush Delta was reduced to an unyielding and unproductive wasteland in terms of vegetation and palm trees that used to be the pride of the people of the area. The situation has continued to worsen because the government had "given a free hand" (p. 54) to the oil companies to do all it can to increase production. Although, according to the narrator, "meant more money in the government coffers to sustain the dictatorship, it also meant total disregard of the Niger Delta people and their environment. Due to the unending circle of exploitation of the environment, the Activist realises that he had returned to a "Niger Delta that had a new face, an ugly or rather sick face that was different from the pristine one he used to know" (p. 54). The burgeoning indiscriminate destruction of the Niger Delta environment is attributive to the subaltern status and the disregard for non-humans by humans. As such, humans tend to trample on the non-human members of the environment to satisfy their unending desire and quest for more wealth, as depicted by the oil companies and the government.

To further identify and attribute the subaltern status to non-human members of the Niger Delta societies, we shall examine how humans treat non-humans as depicted in The Activist. The indigenous peoples of the Niger Delta perceive the oil companies, ran, and operated by humans, as harbingers of death. The indigenous peoples who protest the despoliation of their environment are majorly the proletarian minorities whose major occupations are farming and fishing. They do not have the 
financial and media capacity to challenge the capitalist oil companies and the military government sustained by the proceeds from the unregulated oil exploitation. The multinational oil companies, their foreign allies, and the military government are formidable forces against the poor, proletarian, agrarian, subaltern indigenous peoples and much more against the twice subaltern non-humans in the environment. According to the narrator, "America had joined hands with their local enemies, the oil companies and the military government, whose activities destroyed the people and their environment by spreading fire all over the oil-producing region" (p. 77).

Consequently, the perpetual fire outbreak in the area has hindered the survival of non-human lives in the area. Trees are burnt to ashes, rodents, animals (flying and creeping) are all destroyed, the land is rendered unproductive, vegetation is no longer in existence, the surrounding rivers are equally polluted, and ultimately, the air is polluted. Hence, the entire area is rendered desolate and inhabitable for both humans and non-humans. Non-humans are eventually the most affected because most non-human lives cannot escape the force and speed of such inferno and are most likely to lose their lives in such situations. These are some of the reasons behind the agitations of some environmentalists in the Niger Delta communities. The Activist intensifies his agitation because:

the poisonous methane gas from gas flares, leaking old oil pipes, blowouts, and spillages in the area that had rendered the evergreen wetlands poisoned, the wildlife dead, the aquatic life also dead, and humans in these areas suffering from undiagnosed diseases (Ojaide, 2006, p. 224).

The narrator in The Activist reveals that constant fire outbreak due to sharp practices in the Niger Delta has greatly contributed to climate change. Its effects on the environment and especially on non-human is overwhelming. The air is polluted, the rainwater is polluted, and vegetation dries up due to pollution from the water and oil spills and even fire outbreaks. Consequently, the animals and plants that depend on the vegetation, water and air for survival will ultimately die because humans are bent on maximising profits by engaging in inappropriate and unconventional methods of oil exploitation. The oil companies care nothing about the effects of their activities on the subaltern human talk less of the ultimate subalterns- the non-humans. As the narrator in The Activist highlights these issues, he is certainly more concerned about their effects on the subaltern humans and not the non-human subalterns. According to him,

The air used to be cool because of constant rain and the luxuriant forest, but oil slicks, blowouts, and gas flares had destroyed that life. Even the rain that fell was so soot-black that no more did anybody drink rainwater, which, of all waters, used to be described 
as God-given water. The people had lost their green refuge as well. Their forests used to have deep green and lush foliage, the pride of the tropics, but that had changed since fires often followed oil and gas accidents. (Ojaide, 2006, p. 82)

The narrator is obviously lamenting over the loss of the forest that provides luxury and refuge for humans, which manifests in the form of economic trees and wilderness experience for human sustenance. However, unfortunately for non-humans, they do not have alternatives in terms of reverse osmosis purified water to live on. Either way, they will either die drinking the polluted water or die from thirst for not drinking the polluted water. Therefore, it is a double tragedy for nonhumans in this environment because they are either destroyed by human-induced fire, polluted water or oil spill in an environment that they are major stakeholders in due to human's quest to subordinate and exploit the environment.

Ebi and The Activist appear to show genuine concern about the disappearance of the fishes in the river. However, the concern is not unrelated to the splendour and warmth that comes with the sight of the fishes flying out of the water occasionally and somersaulting back into the water. The thought, however, disappears as soon as it comes. They are surprised at the magnitude of the desolation of the water. They question the whereabouts of the variety of fishes that inhabited the water, the birds that filled the air space, and the supposed healing power of the water. Lo, the reason is not far-fetched, pollution from oil installations, which had either killed them all or forced them to migrate downstream into the ocean. The fishes are also victims of human commercial activities as they are caught and traded in large quantities. Ebi reveals that the small town of Enekerogha "used to be famous for fishing" (Ojaide, 2006, p. 101) in large quantities that are transported to Warri and Port Harcourt for sale.

With the discovery of more oil in the Niger Delta, The Activist expresses deeper concern on the fate of humans and, worst still, nonhumans in his community if nothing is urgently done to curtail the excesses of the oil companies. He affirms that "we are in for disaster, if nothing is done to save our waters, land, and air" (Ojaide, 2006, p. 103). The use of "our" designates possession. It does not present the waters, land, and air as independent and intrinsic members of the ecology but rather subordinate appendages possessed, acquired, or owned by humans. This further highlights the subordinated condition of non-humans in a human-dominated society. The concern expressed here is not basically for the survival of non-humans but, rather, the effect of pollution on non-humans in relation to humans. It appears that The Activist's concern is basically motivated by the fact that he sees the environment as his possession to exploit and that the destruction of non-humans will negatively affect human sustenance. He recounts how his mother sustained her family by living off nonhumans which is a pointer to the fact that humans depend on non-humans for survival. 
Notwithstanding his anthropocentric leaning, The Activist acknowledges that destruction of the non-human subaltern in the environment is tantamount to the destruction of humanity and ecology at large because all constitutes the integral parts of the ecology. According to him, "the Niger Delta was part of its people and just as the land, air, and rivers were being poisoned so were the residents themselves," (p. 104). Obviously, non-humans subaltern cannot speak for or represent themselves; they must be represented by one who often appears as their master, as postulated by Spivak. Hence, the Activist assumes the position of human speaking for non-humans.

There are other instances from The Activist pointing to human's careless attitude towards the non-human subalterns as the major reason for their destruction in society. One of them is the shoddily laid oil pipes in Roko Village and across other adjoining communities, not minding the possible implication of such dangerous installation on the environment. Unfortunately, there was a blowout in Roko Village due to oil pipe leakages and weak and worn-out pipes used to transport crude from one point to another. Consequently, the entire village was burnt to the ground leaving the vegetation destroyed, animals dead, waters, and air polluted. Worst still, the bourgeoisie multinational oil companies fail to take responsibility but rather blame the unfortunate incident on the native proletariat population for sabotaging the oil pipes. This conspiracy further validates humans seemingly determination to annihilate completely nonhuman population in their indecent and irresponsible quest to acquire wealth. Owing to the fire incident, The Activist, Pere and his area boys, and the Student Union stage protests to demand compensation to cater to the village's refugee human population, leaving out the non-human population affected the most. Unfortunately, there is no plan to replenish the destroyed trees, vegetation, animals or clean up the waters and the environment because the protesters' demands are just for the benefit of humans and not the silenced subalterns (non-humans).

Perhaps, because he had attended conferences and symposiums on environmental protection and climate change, The Activist is the only consistent character in the novel that speaks out against human's domination, oppression, and destruction of non-humans in his society. The narrator reveals his reasons for constant agitations and protests the government and the oil companies thus, "- the poisonous methane gas from gas flares, leaking old oil pipes, blowouts, and spillages in the area that had rendered the evergreen wetlands poisoned, wildlife dead, the aquatic life also dead, and humans in these areas suffering from undiagnosed diseases" (Ojaide, 2006, p. 224).

The Activist's agitation is essentially motivated by his desire for wholesome living. Therefore, he shows concern for the non-human, though not as much as he does for the sustenance of humans. However, he understands that the continuous existence of humans cannot be wholly and completely 
divorced from the sustenance of nonhumans and, therefore, strives to speak out for them because they cannot speak for themselves.

On the contrary, in the women's meeting organised by Titi in Warri, Umutor highlights the inability of women to conceive as one of the negative effects of human-induced environmental pollution. Corroborating her view, some members of the women group like Titi, Matije, Maomi and Mrs Taylor point out that environmental pollution has not only affected fertility in women but also men. In so many cases, when women conceive, they give birth to deformed children whom they will end up putting through mercy killings to end their suffering. They also suggest that oil pollution had affected women's lives to the point that it triggers the early menstrual circle at the age of ten and early menopause before forty, which were aberrations before the discovery and exploitation of oil. They also reel out a litany of other health and medical issues caused by the inappropriate exploration and exploitation of oil in the Niger Delta. In their meeting, the women who are human subalterns did not mince words in enumerating and highlighting how they have been affected negatively by the pollution of their environment occasioned by the exploitation activities of the oil companies in the area. However, they fail to consider the fate of non-humans in their environment if they, as humans, can suffer this much. If the proletarian subaltern woman can suffer this much, the non-human subaltern will suffer much more than we can imagine.
In articulating the women's concerns and demands, the narrator captures these in terms that suggest neglect and further validate the subaltern status of non-humans. All the allusions to the destruction of nonhumans are made because of their multiplier effect on humans. The intrinsic values of non-humans are jettisoned and can only be considered if it has any consequence on humans. The narrator explains that:

Pipes had been laid across groves, villages, and towns, intruding into the private spaces of animals, plant, and human populations. All the storks, kingfishers, weaverbirds, sunbirds, and many others had disappeared. The herbs and flowers were almost gone and only the old remembered them by their names. Simple herbs that cured many ailments had disappeared with coming of oil. Now the human population was suffering from ill health because of the disappearance of the sources of their medicines. In addition to loosing curatives for known ailments, new sicknesses had come in without known cures. (Ojaide, 2006, pp. 242-243)

The extract above shows that the people of the area are majorly interested in how oil exploitation and consequential environmental pollution affect the human population. Non-humans are mentioned because their destruction will only amount to scarcity for human wellbeing. The narrator reveals this fact when he says: 
The communities of the oilproducing areas wanted to breathe fresh and clean air; they wanted to drink clean water; they also wanted to swim and fish in their streams and rivers. They did not want to eat fish that harboured poisons in them. They wanted to farm their own crops to be self-reliant on food. They wanted to live a healthy life. And they wanted the damage already done to the environment to be treated seriously. (Ojaide, 2006, p. 243)

It is an indictment on humans in their desire to subdue non-human members of the environment. They are not agitating for a clean air environment because it will benefit non-humans who produce oxygen. The emission of carbon monoxide and other deadly toxic gases can cause harm or even death to humans. They demand clean water, healthy fish, and unpolluted soil because they either serve as drink, food or source of sustenance for them and not because of the intrinsic values they have or for the sustenance of these non-human members. Sadly, they are at the mercy of human exploitation and subordination.

There is also another incident of oil blowout in Ekakpamre village similar but worse than the one that occurs at Roko village. This oil blowout which turns the community into a wasteland, was "exacerbated by a pipe leakage and fuelled by gas flares" (Ojaide, 2006, p. 260). This fire incident is worse than any ever witnessed by the communities, for it rages for days without any effort by Bell Oil to put it out. Consequently, it burns down the entire environment without the intervention of any sort. It destroys the land, animals, vegetation, pollutes the air and even the river. The narrator captures the callousness of the oil company very aptly. In his words, "Bell Oil knew very well that there was a blowout but did not ask its fire-fighting team to put out the fire" (p. 261). This act from the capitalist oil company, managed by humans, caused devastating damage to the non-human habitats of that environment. In a similar manner, human subalterns were equally affected owing to the fact that their houses and properties were destroyed as well as their lives. On the part of nonhumans, they were destroyed and killed beyond imagination. The narrator captures the devastation as follows:

The Uto River was literally burning. Evergreen plants, dry leaves, and shrubs that stood by the river all became combustible materials. The poisonous methane gas fumes engulfed plants, wildlife, and humans around for days. (Ojaide, 2006, p. 261)

From the passages that follow, the narrator reveals that the oil company, driven by their greed and desire to appropriate the entire community for their oil exploitation, will not mind destroying the entire environment to achieve their oppressive capitalist desire. Unfortunately, the ultimate subalterns, the non-human members of the environment, must pay dearly, mostly 
with their lives and existence. Animals that managed to escape the devastation were badly deformed. The Patriot, a local newspaper owned by The Activist, captures some of the non-human survivors of the arson as 'deformed'. The newspaper reveals that "the only frogs seen were deformedone-eyed or one-legged. Blind turtles were caught on land" (Ojaide, 2006, p. 293). And for the rivers, they become dumpsites for chemicals from oil companies. A good example is the Ugunu River which became "brown from Chemicals of oil exploration" (p. 300).

Ironically, the wanton destruction and oppression of non-human subaltern perpetuated by multinational oil companies are only prevalent in the Niger Delta and other postcolonial environments. In The Netherlands, the international headquarters and homeland of Bell Oil, non-humans are treated and related with respect and care. Non-humans in The Netherlands are respected and accorded the right to life, unlike in the Niger Delta. On a fun ride with Erika in The Netherlands, Dennis observes that the environment is completely different from the reality in his Niger Delta. The rivers and lakes they drove past are fresh, clean, and beautiful as they were thousands of years ago. Erika reveals to him that boats that emit dangerous fumes are not allowed on the lakes and rivers to avoid polluting the environment and poisoning the inhabitants of the lake and rivers. As they drove further and stopped by a park for a momentary rest, Dennis was astonished by the difference between his Niger Delta and The Netherlands. He observes that:
Rabbits, squirrels, deer, and different types of birds were not scared by walkers around. Many of the trees must be hundreds of years old and yet looked fresh. A stream flowed through the park; it was shallow but its water was silvery clean. Dennis was surprised at the pristine beauty of the waters compared what had happened to the creeks, streams, and rivers of the Niger Delta. Dutch forests were still fresh despite the centuries the trees had grown, unlike the dying forests of his native Niger Delta. (Ojaide, 2006, p. 318)

The above passage sums up the complex situation of the environmental subalterns of the Niger Delta. The subordination and suppression of non-human subaltern in the Niger Delta are caught up and submerged in complex capitalist and exploitative oil cartels sanctioned by the Nigerian government. The condition of non-human subalterns in the Niger Delta is pitiable because the government and the multinational capitalist class do not care about them and perceive them as objects of gains and exploitation. Their condition is further exacerbated because the human subalterns who sometimes strive to speak for them end up exploiting and subordinating them the more to survive. Therefore, the non-human subalterns are twice and doubly exploited by the capitalist and the subaltern humans, and as such, they are the ultimate subaltern. 


\section{CONCLUSION}

Postcolonial eco literature is beginning to gain more attention as the years go by. However, there should be a paradigm shift from concentrating on humans to paying considerable attention to non-humans as members of our common ecology. Attention should be paid to the fact that they may be obliterated and extinct if their exploitation and destruction by humans are not checked. The purpose of classifying non-humans in this study as the ultimate subaltern is to draw attention to their exploitation and, therefore, call for care, protection, and preservation on their behalf - speaking for. Humans must realise that we cannot go on with destroying non-humans but rather love, care, nurture and be responsible to them. It is to say that humans must adopt a biocentric attitude in their dealings with nature. As vividly articulated in The Activist, the consequences of widespread neglect and destruction of non-humans must be redressed as a matter of urgency to continue living in a sustainable environment. Therefore, humans must respect nature, especially non-humans and treat them with utmost care and love. In turn, nature and non-humans are expected to reciprocate the gesture to attain harmony and balance.

\section{ACKNOWLEDGEMENT}

The authors' sincere gratitude goes to their family members for unalloyed support and colleagues who provided insights that helped shape this research paper. Finally, the authors are truly grateful to Pertanika Journal of Social Sciences and Humanities and the team of reviewers for their comments on the earlier versions and, above all, for accepting to publish this research paper.

\section{REFERENCES}

Ashcroft, B., Griffiths, G., \& Tiffin, H. (2007). Postcolonial studies: The key concepts (2nd ed.). Routledge.

Buttigieg, J. A. (2013). Subaltern social groups in Antonio Gramsci's prison notebooks. In C. Zane (Ed.), The political philosophies of Antonio Gramsci and B.R. Ambedkar: Itineraries of Dalits and subalterns (pp. 35-42). Routledge.

Cayuela, S. R. (2018). Subaltern environmentalism in Can Sant Joan, Catalonia. In S. Cristiano (Ed.), Through the working class: Ecology and society investigated through the lens of labour (pp. 3551). Researchgate. https://www.researchgate.net/ publication/329707906

Darah, G. G., (2011). Revolutionary pressures in Niger Delta literatures. In C. Nwahunanya (Ed.), From boom to doom: Protest and conflict resolution in the literatures of the Niger Delta (2-16). Springfield.

DeLoughrey, E., \& Handley, G. B. (2011). Toward an aesthetics of the earth. In E. DeLaoughrey \& G. B. Handley (Eds.), Postcolonial ecologies: Literatures of the environment (pp. 3-39). Oxford University Press.

Egan, M. (2002). Subaltern environmentalism in the United States: A historiographic review. Environment and History, 8(1), 21-41.

Habib, M. A. R., (2005). Modern literary criticism and theory: A history of literary criticism; from Plato to present. Blackwell.

Huggan, G., \& Tiffin, H. (2009). Postcolonial ecocriticism: Literature, animal, environment. Routledge. 
Iheka, K. (2018). Naturalizing Africa: Ecological violence, agency, postcolonial resistance in African literature. Cambridge University Press.

Lock, C. (2000). Ken Saro-Wiwa, or "The pacification of the primitive tribes of the lower Niger". In C. W. McLuckie \& A. McPhail (Eds.), Ken SaroWiwa: Writer and Political Activist (pp. 3-16). Lynne Rienner.
Ojaide, T. (2006). The activist. Farafina.

Rodney, W. (1972). How Europe underdeveloped Africa. Bogle-L'Ouverture.

Spivak, G. C. (1994). Can the subaltern speak? In P. Williams \& L. Chrisman (Eds.), Colonial discourse and postcolonial theory: A reader (pp. 66-111). Columbia University Press. 
